Frithjof C. Küpper*, Konstantinos Tsiamis, Niko Rainer Johansson, Akira F. Peters, Maria Salomidi, Leonidas Manousakis, Manolis Kallergis, Michael H. Graham, Brian Kinlan ${ }^{\dagger}$, Alexandra Mystikou, Ante Žuljević, Vedran Nikolić, Vasilis Gerakaris, Christos Katsaros ${ }^{a}$ and Panayotis Panayotidis ${ }^{\mathrm{a}}$

\title{
New records of the rare deep-water alga Sebdenia monnardiana (Rhodophyta) and the alien Dictyota cyanoloma (Phaeophyceae) and the unresolved case of deep-water kelp in the Ionian and Aegean Seas (Greece)
}

https://doi.org/10.1515/bot-2019-0033

Received 16 May, 2019; accepted 8 October, 2019; online first 15 November, 2019

Abstract: Parts of the macroalgal flora of the eastern Medi-
terranean remain incompletely known. This applies in par-
ticular to the circalittoral communities. This study, based
upon 2 cruises in the Ionian and Aegean Seas, surveyed
benthic communities from 40 to 150 m depth by remotely-
operated vehicle (ROV) with a special focus on detecting
communities of the Mediterranean deep-water kelp Lami-
naria rodriguezii. These were complemented by shallow-
water surveys on adjacent coastlines by snorkelling and
scuba diving. While no kelp could be detected at any of

${ }^{\dagger}$ Deceased.

${ }^{a}$ Christos Katsaros and Panayotis Panayotidis: These authors contributed equally to the leadership of this project.

*Corresponding author: Frithjof C. Küpper, School of Biological Sciences, University of Aberdeen, Cruickshank Building, St. Machar Drive, Aberdeen AB24 3UU, Scotland, UK; and Marine Biodiscovery Centre, Department of Chemistry, University of Aberdeen, Aberdeen AB24 3UE, Scotland, UK, e-mail: fkuepper@abdn.ac.uk Konstantinos Tsiamis, Maria Salomidi, Vasilis Gerakaris and Panayotis Panayotidis: Hellenic Centre for Marine Research (HCMR), Institute of Oceanography, Anavyssos 19013, Attica, Greece Niko Rainer Johansson: School of Biological Sciences, University of Aberdeen, Cruickshank Building, St. Machar Drive, Aberdeen AB24 3UU, Scotland, UK; and Finnish Museum of Natural History, PO Box 7, 00014 University of Helsinki, Helsinki, Finland

Akira F. Peters: Bezhin Rosko, 40 rue des pêcheurs, 29250 Santec, Brittany, France

Leonidas Manousakis and Manolis Kallergis: Hellenic Center for Marine Research, Underwater Activities Team, ROVs Team, Former American Base Gournes, 71500 Gournes, Crete, Greece Michael H. Graham and Brian Kinlan: Moss Landing Marine Laboratories, 8272 Moss Landing Road, Moss Landing, CA 95039, USA Alexandra Mystikou: School of Biological Sciences, University of Aberdeen, Cruickshank Building, St. Machar Drive, Aberdeen AB24 3UU, Scotland, UK

Ante Žuljević and Vedran Nikolić: Institute of Oceanography and Fisheries, Šet. I, Meštrovića 63, 21000 Split, Croatia

Christos Katsaros: National and Kapodistrian University of Athens, Department of Biology, Athens 157 84, Greece the sites surveyed, ROV surveys of northern Euboia Island revealed the first east Mediterranean record of Sebdenia monnardiana (Sebdeniales, Rhodophyta). Snorkelling surveys on the coast of southeast Kefalonia yielded the first record of the alien alga Dictyota cyanoloma in Greece. This paper reports $r b c \mathrm{~L}$ and SSU sequences for Sebdenia monnardiana, and COI for Dictyota cyanoloma.

Keywords: alien species; COI; Laminaria rodriguezii; rbcL; SSU.

\section{Introduction}

About 270 taxa of brown algae have been recorded until today in the Mediterranean Sea (Ribera et al. 1992, Cormaci et al. 2012). However, when it comes to the eastern basin, the number is far lower. It is not clear whether this is actually due to a lower algal diversity in this part of the Mediterranean Sea or whether it rather reflects fewer biodiversity studies in the eastern in comparison to the Western basin.

Several misidentifications and unconfirmed records as well as recent findings of new species suggest still significant gaps in the knowledge of seaweed diversity of the eastern Mediterranean basin (Tsiamis and Panayotidis 2016). Indeed, a recent increase in phycological expeditions and overall research effort in the eastern basin has revealed numerous new macroalgal records, in particular for Greece such as Discosporangium mesarthrocarpum (Meneghini) Hauck (Tsirika and Haritonidis 2005), Cystoseira schiffneri Hamel [as Cystoseira foeniculacea $\mathrm{f}$ schiffneri (Hamel) Gómez Garreta, Barceló, Ribera et Rull Lluch], and Cystoseira funkii Schiffner ex Gerloff et Nizamuddin (Tsiamis et al. 2016), Cyprus (Tsiamis et al. 2014) and Turkey (Taskin and Ozturk 2007, 2008, Taskin 2008, 2013). Recent findings also include numerous new records of alien species (Tsiamis et al. 2010, 2013), with Caulerpa taxifolia var. distichophylla (Sonder) Verlaque, Huisman et Procaccini occurring over an exceptionally wide depth 
range (Aplikioti et al. 2016). Also, the combined use of algal culturing and molecular techniques (in particular, the Germling Emergence Technique) has unravelled additional new records and hitherto-undescribed taxa from the eastern Mediterranean (Peters et al. 2015).

Populations of the Mediterranean endemic deepwater kelp Laminaria rodriguezii Bornet are found in the western Mediterranean and the Adriatic Sea (Guiry and Guiry 2019). The species may exist also in the eastern basin but still remains undetected. Reports without description or illustration from Turkey (Aysel et al. 2008, Taskin and Özturk 2013) need to be confirmed by new collections. When it comes to the Adriatic Sea, extensive surveys demonstrated a significant decline in the range of the species due to bottom trawling (Žuljevic et al. 2016).

Recently, a computer model was developed which is capable of predicting deep-water kelp habitats in warmtemperate and tropical seas (Graham et al. 2007). At the onset of this study, it appeared as an attractive tool to select target areas for ship-based surveys.

The surveys described here were conducted within the framework of two cruises in the Ionian and Aegean Sea (Greece), aiming to elucidate the potential presence of deep-water kelp communities in the eastern Mediterranean Sea using remotely-operated vehicles (ROVs). In addition, dingy- and shore-based snorkelling and scubadiving surveys of adjacent littoral habitats of interest took place in order to study the macroalgal diversity in more shallow waters. While Laminaria rodriguezii was not detected, we here report new records from Greece of two poorly known taxa, including DNA sequence data: Dictyota cyanoloma Tronholm, De Clerck, Gómez-Garreta et Rull Lluch and Sebdenia monnardiana (Montagne) Berthold.

\section{Materials and methods}

\section{ROV and diving surveys}

Macroalgal surveys were conducted from the R/V Philia (Hellenic Centre for Marine Research) from March 10-17 to October 20-25, 2013. Surveys utilised a remotely operated vehicle (ROV, SAAB Seaeye Falcon, rated to $300 \mathrm{~m}$ depth; www.seaeye.com) equipped with a video camera and robotic arm capable of collecting sessile organisms. In addition, scuba diving and snorkelling in adjacent infralittoral waters were performed, using the dingy of the $\mathrm{R} / \mathrm{V}$ Philia as a support platform. Target areas for Laminaria rodriguezii had been chosen using maps (Figure 1) based upon the prediction model of deep-water kelp habitats based on water transparency and temperature data, previously used in tropical seas (Graham et al. 2007). The model combined satellite-derived data on water transparency and incident irradiance with locally-derived data on bathymetry and water temperature depth profiles to estimate the extent of substrate with enough light to support
A

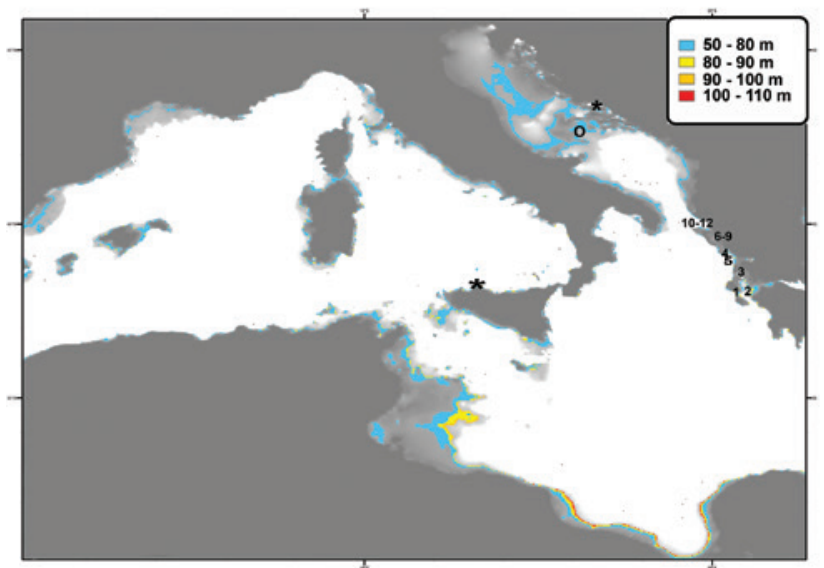

B

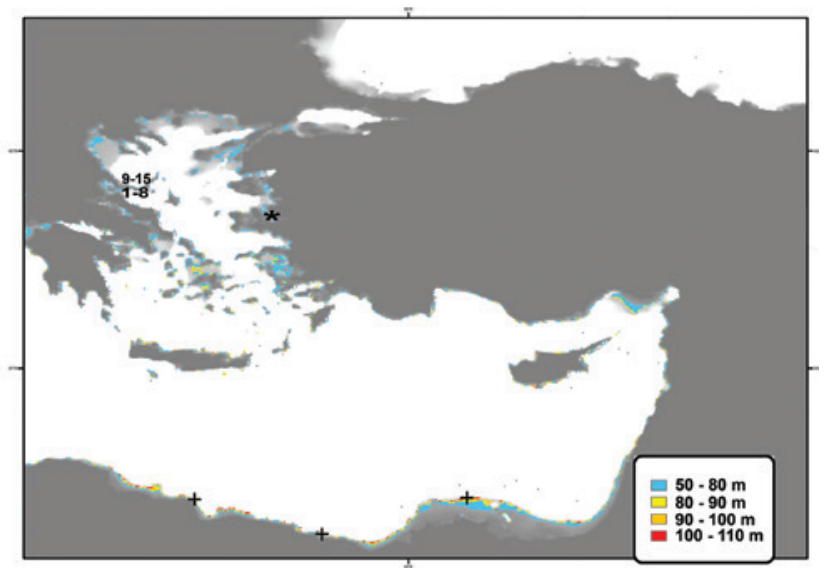

Figure 1: Prediction maps of the potential occurrence of Laminaria rodriguezii in the Eastern Mediterranean.

Coloured shading indicates potential deep-water kelp habitat colour-coded by depth range. These grid cells met all model criteria for kelp occurrence. Grid cells are approximately $3.8 \times 3.8 \mathrm{~km}^{2}$. Predicted kelp habitat shallower than $50 \mathrm{~m}$ is not shown. Black crosses show locations of predicted kelp habitat deeper than $110 \mathrm{~m}$. Grey shading shows ETOPO2v2 bathymetry from 0 m (dark grey shading $=$ land) to the $200 \mathrm{~m}$ isobath (lightest grey shading). The numbers correspond to the ROV surveys detailed in Table 1 . 0 denotes the Jabuka area, where L. rodriguezii has been documented (Žuljevic et al. 2016), while asterisks denote the sites nearest to the ones reported in this study where Dictyota cyanoloma was found. (A) Central Mediterranean. (B) Eastern Mediterranean. 
kelp productivity that existed below the mixed layer depth. This area would be considered the most likely to support deep L. rodriguezii populations, regardless of the quality of the substratum (i.e. soft- vs. hard-bottom).

Surveys in March 2013 spanned the waters from Patras and Kefalonia in the south to Corfu (Kerkyra) in the north, while the surveys in October 2013 extended from Aidipsos (Euboia Island) towards Oreoi, along the mainland coast of Pelio and around the Northern Sporades Islands (Figure 1 and Table 1 for all stations of ROV surveys). These were complemented by snorkelling surveys at sites on adjacent coasts, in particular the surroundings of Argostoli and the coast of southeast Kefalonia, aiming to study the overall shallow algal biodiversity.

\section{Collection of materials}

Seaweed specimens were collected as entire thalli either by the robotic arm of the Seaeye Falcon ${ }^{\mathrm{TM}}$ ROV, by snorkelling or by SCUBA diving. They were subsequently conserved as herbarium specimens on Bristol paper or on microscope slides using acetocarmine as fixative and dye and 50\% Karo $^{\mathrm{TM}}$ syrup as mounting medium (Müller and Ramírez 1994).

Seaweed tissue samples were conserved in parallel in Silica gel and cetyltrimethylammonium bromide (CTAB; e.g. Gachon et al. 2009) buffer for further molecular study. Representative herbarium specimens and permanent slides were deposited at the East Mediterranean Seaweed Herbarium at the Hellenic Centre for Marine Research (HCMR) in Anavyssos, Athens.

\section{DNA extraction, PCR amplification and sequencing}

DNA extractions were carried out using the DNeasy Plant Mini Kit (Qiagen, Hilden, Germany) on material from specimens preserved in silica gel. From Dictyota cyanoloma, the partial mitochondrial cytochrome oxidase I (COI) was amplified using either the primer pair COI-789F \& COI1378R (Silberfeld et al. 2010) or cox1-GazF1 \& cox1-GazR1 (Saunders 2005).

PCR amplification was performed in a total volume of $25 \mu \mathrm{l}$, containing 1.25 units $\mu \mathrm{l}^{-1}(0.25 \mu \mathrm{l}$ stock) of Taq DNA Polymerase (Promega), $5 \mu \mathrm{l} \mathrm{GoTaq}{ }^{\mathrm{TM}}$ buffer, $5 \mathrm{mM} \mathrm{MgCl}_{2}$, $1.25 \mathrm{~mm}$ dNTPs (desoxy nucleotides), $1.87 \mathrm{~mm}$ of each primer and $1 \mu \mathrm{l}$ of template DNA (5-50 ng $\left.\mu^{-1}\right)$. For Dictyota cyanoloma, PCR amplification was conducted with the primer pair cox1-GazF1/cox1-GazR1 (Saunders 2005).
PCR amplification was carried out with an initial denaturation at $94^{\circ} \mathrm{C}$ for $2 \mathrm{~min}$; followed by 35 cycles of amplification consisting of denaturation at $94^{\circ} \mathrm{C}$ for $30 \mathrm{~s}$, annealing at $50^{\circ} \mathrm{C}$ for $30 \mathrm{~s}$ and elongation at $72^{\circ} \mathrm{C}$ for $1 \mathrm{~min}$, followed by a final extension at $72^{\circ} \mathrm{C}$ for $5 \mathrm{~min}$. Returned chromatograms (in ABI/Applied Biosystems format) were imported into BioEdit (Hall 1999) for quality control and resulting consensus sequences were queried against the GenBank online database using BLASTn (Altschul et al. 1997).

For Sebdenia monnardiana, the markers $r b c \mathrm{~L}, 3^{\prime}$-COI and SSU were used. $r b c \mathrm{~L}$ was amplified using the primer pair RbcL77F (Yang et al. 2014) - RbcL952R (Kawai et al. 2007, as Ral-R952), 3'-COI was amplified with primers cox1-789F and cox1-1378R (Silberfeld et al. 2010), and SSU with primers NS1F-NS4R (White et al. 1990), AFP2F (Burkhardt and Peters 1998) and AFP1R (5'-GGTAATGATCCTTCCGCAG-3'). PCR was performed in a total volume of $25 \mu \mathrm{l}$, with $21.5 \mu \mathrm{l}$ of Taq Master Mix stock (VWR International, Haasrode, Belgium), $1.0 \mu \mathrm{l}$ of each primer (10 mM) and 1.5 $\mu \mathrm{l}$ of template DNA. For primers RbcL77F-RbcL952R, PCR included an initial denaturation at $94^{\circ} \mathrm{C}$ for $3 \mathrm{~min}$, followed by 35 cycles of denaturation at $94^{\circ} \mathrm{C}$ for $1 \mathrm{~min}$, annealing at $48^{\circ} \mathrm{C}$ for $30 \mathrm{~s}$ and elongation at $72^{\circ} \mathrm{C}$ for $1 \mathrm{~min}$, followed by a final extension at $72^{\circ} \mathrm{C}$ for $5 \mathrm{~min}$. For primers NS1F-NS4R and AFP2F-AFP1R, PCR included an initial denaturation at $94^{\circ} \mathrm{C}$ for $3 \mathrm{~min}$, followed by 35 cycles of denaturation at $94^{\circ} \mathrm{C}$ for $1 \mathrm{~min}$, annealing at $50^{\circ} \mathrm{C}$ for $30 \mathrm{~s}$ and elongation at $72^{\circ} \mathrm{C}$ for $1 \mathrm{~min}$, followed by a final extension at $72^{\circ} \mathrm{C}$ for $5 \mathrm{~min}$. PCR success was confirmed by 1.2\% agarose gel electrophoresis, and visualised by SYBR safe DNA gel stain (Invitrogen/ ThermoFisher Scientific, Waltham, MA, USA) under UV light. Acquired PCR products were purified using the GeneJET PCR purification Kit (ThermoFisher Scientific, Waltham, MA, USA) and sent off to be sequenced by an external Sanger sequencing service (Source Biosciences, Nottingham, UK). Returned chromatograms were curated similarly as with Dictyota cyanoloma.

\section{Molecular phylogeny}

Phylogenies for Sebdenia monnardiana were calculated separately for SSU and $r b c \mathrm{~L}$ regions. Sequences including other relevant taxa of the Sebdeniales and Rhodymeniales (Table S1 for SSU, Table S2 for $r b c \mathrm{~L}$ ) were aligned and annotated in BioEdit (Hall 1999), and Maximum Likelihood (ML) trees were generated using MEGA7 (Kumar et al. 2016). The ML tree was generated based on the GTR model with Gamma distributed rates among sites, with invariant sites included. One hundred bootstrap replicates were used to assess tree robustness. Members of 
Table 1: Stations and dates of ROV surveys covered here, (A) March 2013 and (B) October 2013.

\begin{tabular}{|c|c|c|c|}
\hline Dive no. & Date & Location & Surveyed depth range \\
\hline \multicolumn{4}{|l|}{ A } \\
\hline 1 & $11 / 03 / 2013$ & $\begin{array}{l}\text { N } 38 \text { 07.570, E } 02027.839 \\
\text { Off Argostoli Gulf (SE), Kefalonia }\end{array}$ & 44-104 m \\
\hline 2 & $11 / 03 / 2013$ & $\begin{array}{l}\text { N } 3806.769 \text {, E } 02027.726 \\
\text { Off Argostoli Gulf (SE), Kefalonia }\end{array}$ & $77-90.5 \mathrm{~m}$ \\
\hline 3 & $12 / 03 / 2013$ & $\begin{array}{l}\text { N } 3827.251, \text { E } 02036.343 \\
\text { Ithaki Straits (N) }\end{array}$ & $95-99 \mathrm{~m}$ \\
\hline 4 & $13 / 03 / 2013$ & $\begin{array}{l}\text { N } 3912.716, \text { E } 02015.030 \\
\text { Off Paxoi Island (E) }\end{array}$ & $60-79.5 \mathrm{~m}$ \\
\hline 5 & $13 / 03 / 2013$ & $\begin{array}{l}\text { N } 3902.582, \text { E } 02014.225 \\
\text { Off Antipaxoi Island (SW) }\end{array}$ & $65-79 m$ \\
\hline 6 & $13 / 03 / 2013$ & $\begin{array}{l}\text { N } 3927.068 \text {, E } 02012.695 \\
\text { Off Xeronisi islet, Corfu Straits (SE) }\end{array}$ & $55.1-61 \mathrm{~m}$ \\
\hline 7 & $13 / 03 / 2013$ & $\begin{array}{l}\text { N } 3927.194 \text {, E } 02012.372 \\
\text { Off Xeronisi islet, Corfu Straits (SE) }\end{array}$ & $54-63 \mathrm{~m}$ \\
\hline 8 & $13 / 03 / 2013$ & $\begin{array}{l}\text { N } 3927.138, \text { E } 02012.307 \\
\text { Off Xeronisi islet, Corfu Straits (SE) }\end{array}$ & $39.5-59 \mathrm{~m}$ \\
\hline 9 & $14 / 03 / 2013$ & $\begin{array}{l}\text { N } 3939.022, \text { E } 01955.533 \\
\text { Off Vidos islet, Corfu Straits (NW) }\end{array}$ & $25-31.6 \mathrm{~m}$ \\
\hline 10 & $15 / 03 / 2013$ & $\begin{array}{l}\text { N } 3953.088, \text { E } 01936.054 \\
\text { Off Ereikoussa Island (E) }\end{array}$ & $14-36 m$ \\
\hline 11 & $15 / 03 / 2013$ & $\begin{array}{l}\text { N } 3944.907, \text { E } 01957.629 \\
\text { N. Corfu Straits }\end{array}$ & $23.5-38 m$ \\
\hline 12 & $15 / 03 / 2013$ & $\begin{array}{l}\text { N } 3945.447, \text { E } 1957.203 \\
\text { N. Corfu Straits }\end{array}$ & $62-66.2 \mathrm{~m}$ \\
\hline \multicolumn{4}{|l|}{ B } \\
\hline 1 & $20 / 10 / 2013$ & $\begin{array}{l}\text { N } 3847.971 \text {, E } 2250.229 \\
\text { Lihadonissia - Strongili Straits }\end{array}$ & $68-69.5 \mathrm{~m}$ \\
\hline 2 & $20 / 10 / 2013$ & $\begin{array}{l}\text { N } 38 \text { 47.107, E } 2249.334 \\
\text { Strongili Islet (South) - Knimidhas Straits }\end{array}$ & $58.3-54 \mathrm{~m}$ \\
\hline 3 & $20 / 10 / 2013$ & $\begin{array}{l}\text { N } 3850.256 \text {, E } 2302.055 \\
\text { Strongili Islet (South) - Knimidhas Straits }\end{array}$ & $92-90 \mathrm{~m} ; 53-51 \mathrm{~m}$ \\
\hline 4 & $21 / 10 / 2013$ & $\begin{array}{l}\text { N } 3854.888, \text { E } 2255.292 \\
\text { Off Agios Konstantinos }\end{array}$ & $66-68 m$ \\
\hline 5 & $21 / 10 / 2013$ & $\begin{array}{l}\text { N } 38 \text { 56.176, E } 2300.249 \\
\text { Oreoi Straits (Glyfa - Agiokampos) }\end{array}$ & $70.2-54 \mathrm{~m}$ \\
\hline 6 & $21 / 10 / 2013$ & $\begin{array}{l}\text { N } 3900.027, \text { E } 2305.050 \\
\text { Off Argyronissi Islet (South) }\end{array}$ & $70 \mathrm{~m}$ \\
\hline 7 & $21 / 10 / 2013$ & $\begin{array}{l}\text { N } 38 \text { 59.931, E } 2304.801 \\
\text { Off Argyronissi Islet (South) }\end{array}$ & $75.1-73 \mathrm{~m}$ \\
\hline 8 & $22 / 10 / 2013$ & $\begin{array}{l}\text { N } 3902.373 \text {, E } 2320.980 \\
\text { Prassonisi Islet South }\end{array}$ & $88-40 m$ \\
\hline 9 & $22 / 10 / 2013$ & $\begin{array}{l}\text { N } 3912.714, \text { E } 2330.073 \\
\text { Off N Skiathos Island }\end{array}$ & $75.6-59 m$ \\
\hline 10 & $23 / 10 / 2013$ & $\begin{array}{l}\text { N } 39 \text { 15.081, E } 2319.984 \\
\text { Off East Pelio }\end{array}$ & $68-44 m$ \\
\hline 11 & $23 / 10 / 2013$ & $\begin{array}{l}\text { N } 3916.768 \text {, E } 2320.421 \\
\text { Off East Pelio (deep) }\end{array}$ & $104-101 \mathrm{~m}$ \\
\hline 12 & $23 / 10 / 2013$ & $\begin{array}{l}\text { N } 39 \text { 16.316, E } 2320.438 \\
\text { Off East Pelio }\end{array}$ & $96.6-92 \mathrm{~m}$ \\
\hline 13 & $24 / 10 / 2013$ & $\begin{array}{l}\text { N } 3905.659, \text { E } 2302.775 \\
\text { Trikeri Lighthouse }\end{array}$ & $70-76 \mathrm{~m}$ \\
\hline 14 & $24 / 10 / 2013$ & $\begin{array}{l}\text { N } 3905.201 \text {, E } 2307.529 \\
\text { Off Southern Pelio }\end{array}$ & $64-17 m$ \\
\hline 15 & $24 / 10 / 2013$ & $\begin{array}{l}\text { N } 3903.707, \text { E } 2321.516 \\
\text { Off Southern Pelio }\end{array}$ & $64-43 \mathrm{~m} ; 39-76 \mathrm{~m}$ \\
\hline
\end{tabular}


Rhodymeniales were used as outgroups in the analyses, Perbella minuta (Kylin) Filloramo et G.W. Saunders and Hymenocladia chondricola (Sonder) J.A. Lewis in the SSU phylogeny and Rhodymenia pseudopalmata (J.V. Lamouroux) P.C. Silva and Dictyothamnion saltatum A.J.K. Millar in the $r b c L$ phylogeny.

\section{Results}

Despite intensive survey efforts totalling 27 ROV dives in the areas where the prediction model had suggested its occurrence, over 10 days during 2 separate cruises, Laminaria rodriguezii was not detected at any of the sites, neither in the Ionian Sea nor in the NW Aegean.

Dictyota cyanoloma, easily recognisable by the characteristic blue iridescence of its thallus margins (Figure 2), was found during snorkelling surveys in a shallow-water community at approx. $0.5-1 \mathrm{~m}$ depth on a rocky coast of SW Kefalonia in Argostoli Bay (Kefalonia Island - 38.2020222 $\left.\mathrm{N} ; 20.4859361^{\circ} \mathrm{E}\right)$ together with Dictyota dichotoma var. intricata (C. Agardh) Greville and Ellisolandia elongata (J. Ellis et Solander) K.R. Hind et G.W. Saunders, adjacent to ROV station 1 (Figure 2), on March 11, 2013. A specimen was deposited in the East Mediterranean Seaweed Herbarium, Athens (110313-6 HCMR Herbarium). The taxon was easily identified given the blue iridescence of its margins in sunlit shallow waters. The COI sequence (Table 2) showed complete identity to those obtained from specimens in Spain (Tronholm et al. 2010).

Sebdenia monnardiana was found in a rhodolith bed at $60.3 \mathrm{~m}$ depth off northern Euboia (N 39 03.707, E 23 21.516) during ROV dive no. 15 on Oct. 24, 2013 (Figure 3A). It was about $12 \mathrm{~cm}$ wide and $10 \mathrm{~cm}$ tall, and attached

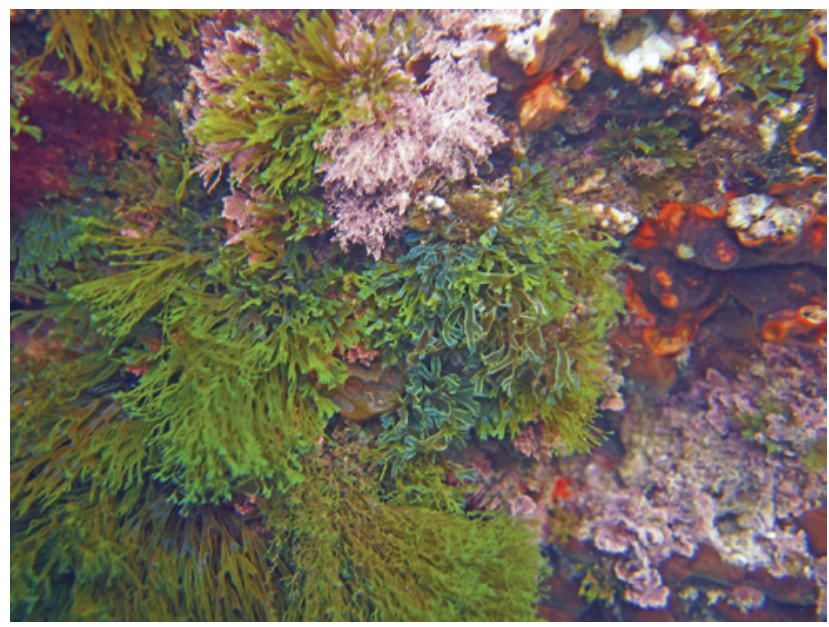

Figure 2: Dictyota cyanoloma in situ on the coast of SW Kefalonia. through a small holdfast on a coralline boxwork rhodolith. The morphological characteristics were cartilaginous texture, reddish colouration (but turning yellowish when dried as a herbarium specimen), few anastomoses of the lobes present, and a smooth margin. In cross section (about $500 \mu \mathrm{m}$ thick), an interwoven filamentous medulla (filaments about $10 \mu \mathrm{m}$ in diameter) surrounded by layers of cortical cells could be observed. Inner cortical cells were bigger, about $60-70 \mu \mathrm{m}$ in diameter, while outer cortical cells were small, about $3 \mu \mathrm{m}$ in diameter in surface view. Double connections among the inner

Table 2: Nucleotide sequences obtained in this study and corresponding database accession numbers.

\begin{tabular}{lll}
\hline Taxon & Locus & Accession numbers \\
\hline Dictyota cyanoloma & COI & LT618775 \\
Sebdenia monnardiana & $r b c \mathrm{~L}$ & MN642085 \\
& COI & MN642084 \\
& SSU & MN533961 \\
\hline
\end{tabular}

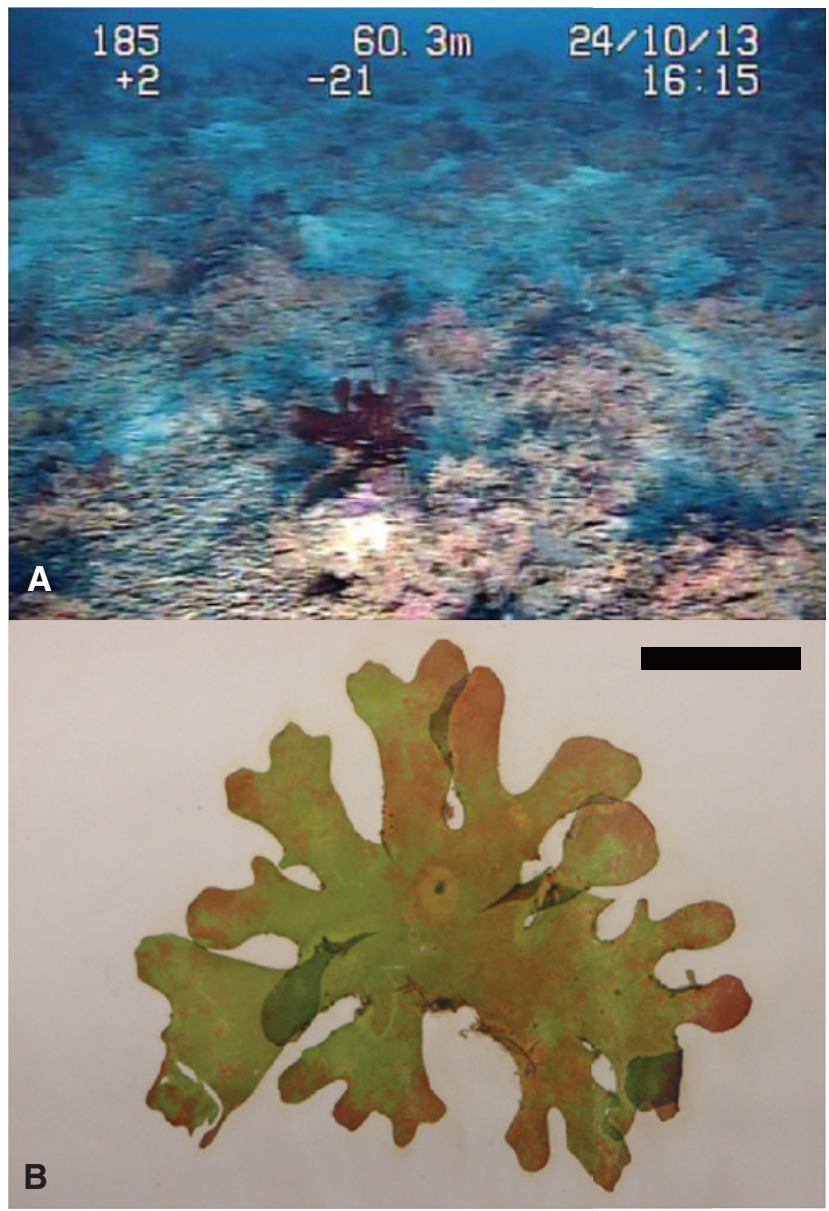

Figure 3: Sebdenia monnardiana.

(A) In situ at $60.3 \mathrm{~m}$ depth off northern Euboia. (B) Herbarium specimen (scale bar: $3 \mathrm{~cm}$ ). 

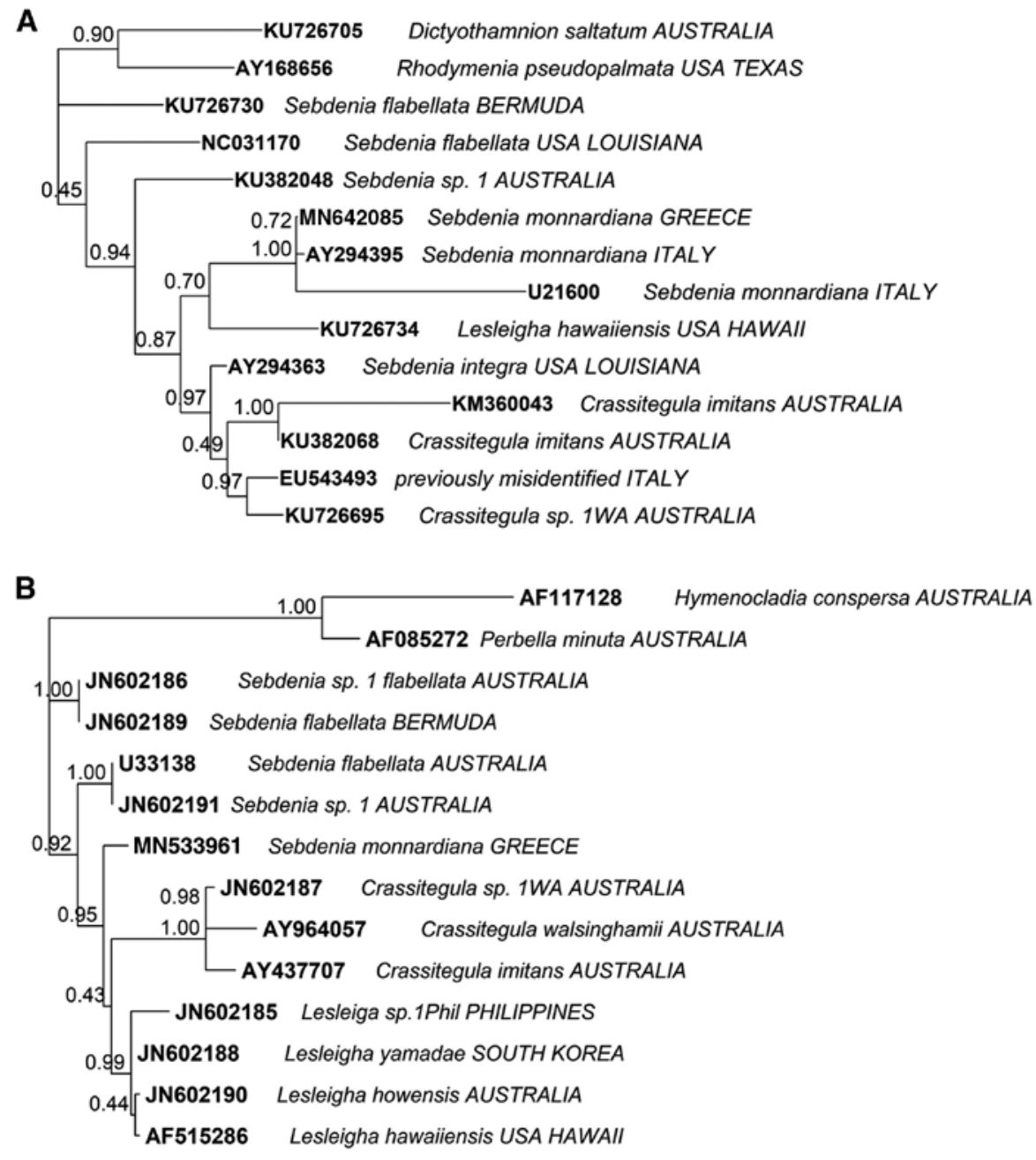

Figure 4: Maximum likelihood phylogenies of $r b c L$ (A) and SSU (B) for the Sebdenia monnardiana specimen reported here (marked "GREECE”). Values close to nodes represent their support from 100 bootstrap replicates.

cortical cells were present. No reproductive organs were observed. A specimen was deposited in the East Mediterranean Seaweed Herbarium, Athens (241013-1 HCMR Herbarium; Figure 3B). A complete sequence of SSU as well as partial sequences of $r b c \mathrm{~L}$ and COI were obtained (Table 2). Maximum Likelihood phylogenies were calculated for $r b c \mathrm{~L}$ (Figure 4A) and SSU (Figure 4B).

\section{Discussion}

\section{Deep-water kelp in Greece?}

Despite the survey efforts within the framework of the two cruises covered here, the question of the existence of
Laminaria rodriguezii in east Mediterranean waters has to be considered unresolved. As of now, L. rodriguezii has never been observed in Greek waters. Previous records of Laminaria digitata (Hudson) Lamouroux and Saccharina latissima (Linnaeus) Lane, Mayes, Druehl \& Saunders from the Ionian Sea cannot be verified due to loss of these materials during World War II. These possibly referred to Saccorhiza polyschides and not to deep-water kelps because they were based on specimens cast ashore together with seagrass leaves. The absence of observations during the cruises does not constitute conclusive negative evidence considering the patchy occurrence in areas such as the Adriatic where numeric prediction modelling would suggest a more contiguous occurrence (Žuljevic et al. 2016). Also, the intense bottom trawling activity in part of the Greek waters has to be taken into account. Even 
if $L$. rodriguezii had existed in any of the areas surveyed here, its communities may well have been exterminated in recent decades, in analogy to its disappearance from $>95 \%$ of its previously-documented range in the Adriatic Sea due to bottom trawling (Žuljevic et al. 2016). Indeed, at several of the sites, the impacts of bottom trawling (trawling scars) were obvious during the ROV surveys.

Another hypothesis that could potentially account for the lack of Laminaria rodriguezii observations during the surveys reported here is that the model (Graham et al. 2007), which was developed and successfully tested for tropical locations (e.g. Galapagos), insufficiently reflects the strongly seasonal environmental conditions of the Mediterranean, and that the model may need further refinement. Specifically, although the model developed by Graham et al. (2007) predicted locations in our study region where deep L. rodriguezii may occur, if L. rodriguezii is less tolerant of lower irradiance levels than the physiological parameters used in the model, then the predicted areas in Greek waters may have been over-estimates of where $L$. rodriguezii could persist.

Without doubt, the ROV surveys conducted within the framework of this study have to be considered insufficient for conclusively answering the question of the occurrence of Laminaria rodriguezii in eastern Mediterranean waters. We suggest that fishermen, ROV operators and divers operating in the depth range of 40-150 m for unrelated purposes in the eastern Mediterranean should be given adequate instructions to be able to recognise this species in case of chance encounters.

\section{Dictyota cyanoloma}

The recently described Dictyota cyanoloma (Dictyotales, Phaeophyceae; Tronholm et al. 2010) is known from the Mediterranean coast of Spain (Tronholm et al. 2010, Bárbara et al. 2015), the Adriatic, Portugal, Madeira, the Azores and Canary Islands (Tronholm et al. 2010). Its phylogenetic affinities have been established by sequences of partial LSU rDNA, rbcL, psbA, cox1, cox3, and nad1 (Tronholm et al. 2010). Recent findings from Turkey (Taskin 2013) constitute the first records for the eastern Mediterranean so far.

The record of this taxon from Kefalonia Island reported here supports the notion that the eastern Mediterranean remains incompletely surveyed for its macroalgal diversity. DNA sequences unambiguously confirmed that the material belongs to Dictyota cyanoloma. In the eastern Mediterranean, $D$. cyanoloma has been previously reported from the Aegean coast of Turkey near Izmir (Taskin 2013), but not from Greek waters. This record suggests a contiguous, albeit rare distribution of this taxon in the shallow infralittoral from the Azores, Madeira and the Canary Islands, and throughout the Mediterranean, including the Adriatic to the Mediterranean coast of Turkey. Recent work (Steen et al. 2017) has shown that this taxon is not native to Europe, but an introduction which has been present in the Adriatic as early as 1935 . The same study (Steen et al. 2017) showed that D. cyanoloma is also present in western and southern Australia.

\section{Sebdenia monnardiana}

Sebdenia monnardiana is known only from circalittoral habitats of the western Mediterranean - but not yet from the eastern Mediterranean. No SSU sequences, only $r b c \mathrm{~L}$ sequences are available for $S$. monnardiana so far.

The finding presented here constitutes a new record for Greece and, indeed, the entire eastern Mediterranean. The Sebdeniaceae was erected by Kylin (1932) in order to accommodate Sebdenia monnardiana originally described from the North African coast of the western Mediterranean. Athanasiadis (2002; p. 120) reported it to be "the largest Mediterranean red alga, reaching 1 meter in diameter". Compared to this, the specimen reported here (of only about $10 \mathrm{~cm}$ size) is very small. The SSU sequence reported here is the first sequence of this important marker for S. monnardiana, which is significant since $S$. monnardiana is the type species for the genus Sebdenia and the order Sebdeniales (Withall and Saunders 2006), and it is clearly difficult to collect. Our $r b c \mathrm{~L}$ sequence matches two sequences reported previously for this taxon from Italy (especially AY294395.1 with 99.53\% identity for 100\% query cover, but also U21600. 1, with $98.94 \%$ identity). The specimen corresponding to AY294395 was collected at Lachea Island, near Catania, Italy, by G. Furnari and M. Cormaci in October 1994, and is surely a correctly identified S. monnardiana (Gavio et al. 2005). The lower similarity value for U21600 is due to missing data and possible errors in this older sequence; nevertheless it forms a clade with AY294395 and our sequence. Sequence similarity of our specimen with U21600 and AY294395 confirms the morphological identification of our material. In contrast, the sequence EU543493 for an alga from central Italy is problematical. It was submitted to NCBI by R. D’Archino, N. Abdelahad, and G. Procaccini and is only $89.4 \%$ identical with EU543493 and $90.6 \%$ with our sequence. However, it appears to be a good $r b c \mathrm{~L}$ sequence (most substitutions are at third base positions) and likely belongs to a related species of as yet unknown identity, which in our 
rbcL tree (Figure 4A) forms a clade with Crassitegula sp. from Australia.

Acknowledgements: We would like to thank the entire crew of R/V Philia (HCMR), led by Cptn. Manolis Kokos, for their smooth conductance of both cruises and great hospitality on board. Thanks are also due to Max Overstrom-Coleman (Moss Landing) for supporting the Ionian Sea cruise in March 2013, to Conxi Rodriguez-Prieto (Girona) for identifying Sebdenia monnardiana, and to Dawn Shewring (Aberdeen) for supporting the molecular work. We also acknowledge many years of funding support from the TOTAL Foundation (Paris, Brown algal biodiversity and ecology in the East M) to FCK, PP, KT and CK, and from the UK Natural Environment Research Council to FCK (grants NE/D521522/1 and NE/J023094/1, funder id: http://dx.doi.org/10.13039/100008668, Oceans 2025/ WP 4.5). AM received joint PhD funding from the School of Biological Sciences, University of Aberdeen, and the Falkland Islands Government. We are also grateful for funding from the MASTS pooling initiative (The Marine Alliance for Science and Technology for Scotland). MASTS is funded by the Scottish Funding Council (grant reference HR09011) and contributing institutions.

\section{References}

Altschul, S.F., T.L. Madden, A.A. Schaffer, J.H. Zhang, Z. Zhang, W. Miller and D.J. Lipman. 1997. Gapped BLAST and PSI-BLAST: a new generation of protein database search programs. Nucleic Acids Res. 25: 3389-3402.

Aplikioti, M., P. Louizidou, A. Mystikou, M. Marcou, P. Stavrou, S. Kalogirou, K. Tsiamis, P. Panayotidis and F.C. Küpper. 2016. Further expansion of the alien seaweed Caulerpa taxifolia var. distichophylla (Sonder) Verlaque, Huisman \& Procacini (Ulvophyceae, Bryopsidales) in the Eastern Mediterranean Sea. Aquat. Invasions 11: 11-20.

Athanasiadis, A. 2002. Taxonomy and systematics of Rhodophyta with reference to the Mediterranean taxa. Flora Mediterranea 19: 93-167.

Aysel, V., H. Erdugan, B. Dural and E.Ş. Okudan. 2008. A survey of marine algae and seagrasses of Istanbul (Turkey). J. Black Sea/ Medit. Environ. 14: 129-144.

Bárbara, I., O. De Clerk, V. García-Redondo, V. Peña, A. GarcíaFernández, C. Peteiro and N. Sánchez. 2015. Nuevas citas y adiciones corológicas para la flora bentónica marina del Atlántico Ibérico. Acta Bot. Malacit. 40: 191-198.

Burkhardt, E. and A.F. Peters. 1998. Molecular evidence from nrDNA ITS sequences that Laminariocolax (Phaeophyceae, Ectocarpales sensu lato) is a worldwide clade of closely related kelp endophytes. J. Phycol. 34: 682-291.

Cormaci, M., G. Furnari, M. Catra, G. Alongi and G. Giaccone. 2012. Erratum. Flora marina bentonica del Mediterraneo: Phaeophyceae. Boll. Accad. Gioenia 45: 509-510.
Gachon, C.M.M., M. Strittmatter, D.G. Müller, J. Kleinteich and F.C. Küpper. 2009. Differential host susceptibility to the marine oomycete pathogen Eurychasma dicksonii detected by real time PCR: not all algae are equal. Appl. Environ. Microbiol. 75: 322-328.

Gavio, B., E. Hickerson and S. Fredericq. 2005. Platorna chrysymenioides sp. nov. (Schizymeniaceae), and Sebdenia integra sp. nov. (Sebdeniaceae), two new red algal species from the Northwestern Gulf of Mexico, with a phylogenetic assessment of the Cryptonemiales Complex (Rhodophyta). Gulf Mex. Sci. 23: 38-57.

Graham, M.H., B.P. Kinlan, L.D. Druehl, L.E. Garske and S. Banks. 2007. Deep-water kelp refugia as potential hotspots of tropical marine diversity and productivity. Proc. Natl. Acad. Sci. U.S.A. 104: 16576-16580.

Guiry, M.D. and G.M. Guiry. 2019. AlgaeBase. World-wide electronic publication. http://www.algaebase.org. In National University of Ireland, Galway.

Hall, T.A. 1999. BioEdit: a user-friendly biological sequence alignment editor and analysis program for Windows 95/98/NT. Nucl. Acids. Symp. Ser. 41: 95-98.

Kawai, H., T. Hanyuda, S.G.A. Draisma and D.G. Müller. 2007. Molecular phylogeny of Discosporangium mesarthrocarpum (Phaeophyceae) with a reinstatement of the order Discosporangiales. J. Phycol. 43: 186-194.

Kumar, S., G. Stecher and K. Tamura. 2016. MEGA7: Molecular Evolutionary Genetics Analysis Version 7.0 for Bigger Datasets. Mol. Biol. Evol. 33: 1870-1874.

Kylin, H. 1932. Die Florideenordnung Gigartinales. Lunds Univ. Arsskrift, N.F., Andra Afdeln. 28: 1-88.

Müller, D.G. and M.E. Ramírez. 1994. Filamentous brown algae from the Juan Fernandez Archipelago (Chile): contribution of laboratory culture techniques to a phytogeographic survey. Bot. Mar. 37: 205-211.

Peters, A.F., L. Couceiro, K. Tsiamis, F.C. Küpper and M. Valero. 2015. Barcoding of cryptic stages of marine brown algae isolated from incubated substratum reveals high diversity in Acinetosporaceae (Ectocarpales). Cryptogamie Algologie 36: 3-29.

Ribera, M.A., A.G. Garreta, T. Gallardo, M. Cormaci, G. Furnari and G. Giaccone. 1992. Checklist of Mediterranean seaweeds.1. Fucophyceae (Warming, 1884). Bot. Mar. 35: 109-130.

Saunders, G.W. 2005. Applying DNA barcoding to red macroalgae: a preliminary appraisal holds promise for future applications. Proc. Roy. Soc. Lond. B 360: 1879-1888.

Silberfeld, T., J.W. Leigh, H. Verbruggen, C. Cruaud, B. de Reviers and F. Rousseau. 2010. A multi-locus time-calibrated phylogeny of the brown algae (Heterokonta, Ochrophyta, Phaeophyceae): investigating the evolutionary nature of the "brown algal crown radiation”. Mol. Phylogenet. Evol. 56: 659-674.

Steen, F., J. Aragay, A. Žuljevic, H. Verbruggen, F.P. Mancuso, F. Bunker, D. Vitales, A.G. Garreta and O. De Clerck. 2017. Tracing the introduction history of the brown seaweed Dictyota cyanoloma (Phaeophyceae, Dictyotales) in Europe. Eur. J. Phycol. 52: 31-42.

Taskin, E. 2008. The marine brown algae of the east Aegean Sea and Dardanelles II. Ectocarpaceae, Chordariaceae and Scytosiphonaceae. Cryptogamie Algologie 29: 173-186.

Taskin, E. 2013. New records of three Dictyotalean brown algae for Turkey. Bot. Mar. 56: 299-302. 
Taskin, E. and M. Ozturk. 2007. The marine brown algae of the East Aegean Sea and Dardanelles - I. Ectocarpaceae, Pylaiellaceae, Chordariaceae, Elachistaceae and Giraudiaceae. Cryptogamie Algologie 28: 169-190.

Taskin, E. and M. Ozturk. 2008. A first report on the marine algal flora of Turkey: Pseudolithoderma adriaticum (Phaeophyceae, Lithodermataceae). Fresenius Environ. Bull. 17: 617-619.

Taskin, E. and M. Özturk. 2013. Türkiye deniz algleri. I. Phaeophyceae. Celal Bayar University, Matbaasi, Manisa, Turkey. pp. ii + 229.

Tronholm, A., F. Steen, L. Tyberghein, F. Leliaert, H. Verbruggen, M.A. Ribera Siguan and O. de Clerck. 2010. Species delimitation, taxonomy, and biogeography of Dictyota in Europe (Dictyotales, Phaeophyceae). J. Phycol. 46: 1301-1321.

Tsiamis, K. and P. Panayotidis. 2016. Seaweeds of the Greek coasts. Rhodophyceae: Ceramiales. Acta Adriat. 57: 227-250.

Tsiamis, K., B. Montesanto, P. Panayotidis, C. Katsaros and M. Verlaque. 2010. Updated records and range expansion of alien marine macrophytes in Greece (2009). Mediterr. Mar. Sci. 11: 61-79.

Tsiamis, K., P. Panayotidis, M. Salomidi, A. Pavlidou, J. Kleinteich, K. Balanika and F.C. Küpper. 2013. Macroalgal community response to re-oligotrophication: Saronikos Gulf. Mar. Ecol.Prog. Ser. 472: 73-85.

Tsiamis, K., E. Taskin, S. Orfanidis, P. Stavrou, M. Argyrou, P. Panayotidis, T. Tsioli, B. Ali Cicek, M. Marcou and F.C. Küpper. 2014. Checklist of seaweeds of Cyprus (Mediterranean Sea). Bot. Mar. 57: 153-166.

Tsiamis, K., M. Salomidi, E. Kytinou, Y. Issaris and V. Gerakaris. 2016. On two new records of rare Cystoseira taxa (Fucales, Phaeophyceae) from Greece (Eastern Mediterranean). Bot. Mar. 59: 73-77.

Tsirika, A. and S. Haritonidis. 2005. A survey of the benthic flora in the National Marine Park of Zakynthos (Greece). Bot. Mar. 48: 38-45.

White, T.J., T. Bruns, S. Lee and J.W. Taylor. 1990. Amplification and direct sequencing of fungal ribosomal RNA genes for phylogenetics. In: (M.A. Innis, D.H. Gelfand, J.J. Sninsky and T.J. White, eds) $P C R$ protocols: a guide to methods and applications. Academic Press, Inc., New York, NY. pp. 315-322.

Withall, R.D. and G.W. Saunders. 2006. Combining small and large subunit ribosomal DNA genes to resolve relationships among orders of the Rhodymeniophycidae (Rhodophyta): recognition of the Acrosymphytales ord. nov. and Sebdeniales ord. nov. Eur. J. Phycol. 41: 379-394.

Yang, E.C., A.F. Peters, H. Kawai, R. Stern, T. Hanyuda, I. Barbara, D.G. Müller, M. Strittmatter, W.F. Prud'Homme van Reine and F.C. Küpper. 2014. Ligulate Desmarestia (Desmarestiales, Phaeophyceae) revisited: $D$. japonica sp. nov. and $D$. dudresnayi differ from D. ligulata. J. Phycol. 50: 149-166.

Žuljević, A., A.F. Peters, V. Nikolić, B. Antolić, M. Despalatović, I. Cvitković, I. Isajlović, H. Mihanović, S. Matijević, D.M. Shewring, S. Canese, C. Katsaros and F.C. Küpper. 2016. The Mediterranean deep-water kelp Laminaria rodriguezii is an endangered species in the Adriatic Sea. Mar. Biol. 163: 69.
Supplementary Material: The online version of this article offers supplementary material (https://doi.org/10.1515/bot-2019-0033). Article note: This paper is dedicated to the memory of Brian Kinlan (November 5, 1977-January 27, 2017) who untimely passed away during the writing of this manuscript.

\section{Bionotes}

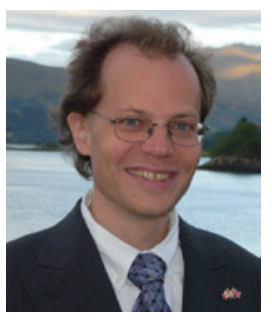

\section{Frithjof C. Küpper}

School of Biological Sciences, University of Aberdeen, Cruickshank Building, St. Machar Drive, Aberdeen AB24 3UU, Scotland, UK; and Marine Biodiscovery Centre, Department of Chemistry, University of Aberdeen, Aberdeen AB24 3UE, Scotland, UK

fkuepper@abdn.ac.uk

Frithjof C. Küpper has held the Chair in Marine Biodiversity at the University of Aberdeen (Oceanlab) since 2011. Over the past 25 years, he has studied the biodiversity and biochemistry of marine plants/algae - especially abiotic and biotic stress. He conducted graduate studies at Roscoff and Konstanz for a joint French-German $\mathrm{PhD}$. His research resulted in the finding of iodide serving as an inorganic antioxidant in kelp, the first described from a living system, impacting atmospheric and marine chemistry. A certified scientific diver, Frithjof has worked extensively in the South Atlantic (Ascension and Falkland Islands), but also in the Antarctic Peninsula and the Canadian Arctic for algal diversity-related projects.

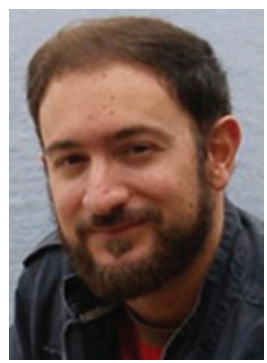

Konstantinos Tsiamis

Hellenic Centre for Marine Research (HCMR), Institute of Oceanography, Anavyssos 19013, Attica, Greece

Konstantinos Tsiamis is a marine biologist, focusing on seaweeds and seagrasses: biodiversity, biology, ecology and taxonomy, with emphasis on alien species and pollution impacts in the Mediterranean Sea. He has a broad experience in marine biodiversity surveys, carried out in the Mediterranean and the Atlantic Ocean, as well as in laboratory analyses. He has participated in $>40$ research projects on the marine environment, is a (co)author of $>50$ publications in peer-reviewed publications, participated in numerous symposia and workshops, and obtained several scholarships. He is an expert scuba diver with long experience in sampling seaweeds and seagrasses. 


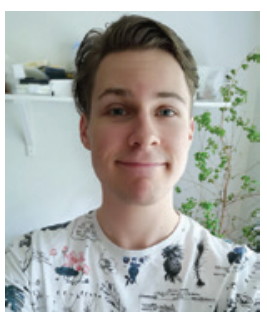

Niko Rainer Johansson

School of Biological Sciences, University of Aberdeen, Cruickshank Building, St. Machar Drive, Aberdeen AB24 3UU, Scotland, UK; and Finnish Museum of Natural History, PO Box 7, 00014 University of Helsinki, Helsinki, Finland
Niko Rainer Johansson is a Finnish biologist, who completed his degree at the University of Aberdeen. His Honour's thesis used DNA barcoding in macroalgal species discovery from oceanic islands, supervised by Prof. Frithjof $C$. Küpper. Niko has also worked on body size evolution in lepidopterans and is involved in biology education and the International Biology Olympiad. In August 2019, Niko will begin his $\mathrm{PhD}$ project on lichen algal-fungal interactions at the University of Helsinki.

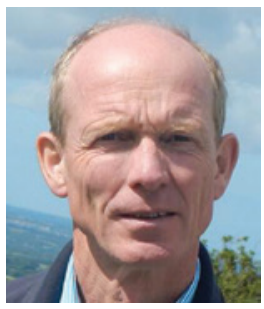

\section{Akira F. Peters}

Bezhin Rosko, 40 rue des pêcheurs, 29250 Santec, Brittany, France

Akira F. Peters is a gentleman scientist. Since the beginning of his scientific career in 1980 he has worked on life histories, taxonomy, phylogenetics, ecology, pathology, genetics, development, cultivation and utilisation of brown algae. He has a PhD from Konstanz University, Germany, is director of the enterprise Bezhin Rosko (www. bezhinrosko.com) and lives near Roscoff in Brittany, NW France. His main techniques are isolation, purification and laboratory cultivation of seaweed microstages.

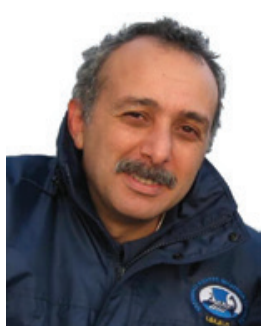

\section{Leonidas Manousakis}

Hellenic Center for Marine Research, Underwater Activities Team, ROVs Team, Former American Base Gournes, 71500 Gournes, Crete, Greece

Leonidas Manusakis is an ROV Pilot and hydroacoustic and oceanographic scientific instrumentation engineer at the Hellenic Center for Marine Research (HCMR). A recipient of a European Commet Scholarship in 1985, he was introduced to the Electronic Design and Fabrication Department of EGC Electronique (France) where he designed and programmed several devices with the use of microcontrollers. In 2008 he designed and upgraded the MaxRover II with optical fibres with the help of his HCMR co-workers. He had participated in projects financed by international organisations as the following ones: i. France, EEC “Commet”, Electronic Development at the "EGC Electronique", 6 months. a. Through the Commet program, supervisor for designing 2 products at the Office of Studies of the company. b. Organizing the study in the sector of designing LCD displays. c. Market research and cost of production for a couple of products of the company. ii. EPET II. "Development of the Greek fisheries." IMBC jointly with the National Center of Marine Research (Athens), the Agricultural Bank of Greece (ABG), and AnagnopoulosPetsalis Ltd. iii. Assessment of small pelagic fishes. Evaluation of their abundance and spatial distribution in North Aegean Sea. The project was financed by the Greek Ministry of Agriculture and the Greek Ministry of Research and Technology. iv. "Evaluation of the Southern Greek anchovy stocks" (1998). v. "Investigation of the intensity of fishing activity." (1998). vi. "Evaluation of the Southern Greek sardine stocks" (1999) Since 1993, he is member of the Association Hellenique d'Ingenieurs Technologues. 